\title{
Can art museums help environmental education? An interdisciplinary vision to promote meaningful learning
}

\author{
Fernando Echarri \\ Environmental Biology Department, University of Navarra, Museum University of \\ Navarra, Pamplona, Spain. fecharri@unav.es \\ ORCID: https://orcid.org/0000-0003-1886-8927
}

[Recibido: 6 Abril 2020. Revisado: 1 Julio 2020. Aceptado: 8 Diciembre 2020]

\begin{abstract}
Environmental education is a discipline that tries to find new methodologies and tools to advance in the achievement of its goals. The museum education proposed by art museums, because of its specific methods and power of significance, can be a way forward for environmental education that is worth exploring. The theory of meaningful learning can be used by both disciplines to support and achieve more meaningful, and therefore lasting, learning among people. The complementarity and synergy between these disciplines can be established from their points of conceptual coincidence. The main research goals of this article have been two: to study and show the intrinsic complementarity of these disciplines from a conceptual viewpoint, and to show how their combined strength and complementarity can inspire specific educational proposals for the challenges of education in the twenty-first century. For example, those that focus on educating on the complexity of the world. The presentation and discussion of this conceptual framework may suggest educational instructions that move towards the interdisciplinary nature of environmental education, using as an educational resource that which is housed in art museums.
\end{abstract}

Keywords: Environmental education; Meaningful learning; Museology; Complexity

\section{¿Pueden los museos de arte ayudar a la educación ambiental? Una visión interdisciplinaria para promover un aprendizaje significativo}

Resumen: La educación ambiental es una disciplina que busca encontrar nuevas metodologías y herramientas para avanzar en el logro de sus metas. La educación museística propuesta por los museos de arte, debido a sus métodos específicos y su poder de importancia, puede ser un camino a seguir para la educación ambiental que vale la pena explorar. La teoría del aprendizaje significativo puede ser utilizada por ambas disciplinas para apoyar y lograr un aprendizaje más significativo y, por lo tanto, duradero entre las personas. La complementariedad y sinergia entre estas disciplinas se puede establecer a partir de sus puntos de coincidencia conceptual. Los principales objetivos de investigación de este artículo han sido dos: estudiar y mostrar la complementariedad intrínseca de estas disciplinas desde un punto de vista conceptual, y mostrar cómo su fuerza y complementariedad combinadas pueden inspirar propuestas educativas específicas para los desafíos de la educación en el siglo XXI. siglo. Por ejemplo, aquellos que se enfocan en educar sobre la complejidad del mundo. La presentación y discusión de este marco conceptual puede sugerir instrucciones educativas que avancen hacia la interdisciplinariedad de la educación ambiental, utilizando como recurso educativo lo que se alberga en los museos de arte.

Palabras Clave: Educación ambiental; Aprendizaje significativo; Museología; complejidad

Para citar este artículo: Echarri, F. (2020) Can art museums help to the environmental education? Interdisciplinary contents and a complex vision of the world in the XXI century. Revista de Educación Ambiental y Sostenibilidad 2(2), 3203. doi: 10.25267/Rev_educ_ambient_sostenibilidad.2020.v2.i2.2303 


\section{Introduction}

Art museums can stir motivation and offer experiences that take advantage of the presence of objects and exhibits not found at schools (Rivière, 1989). They may use their potential to educate many types of visitors, and pass on knowledge in specific areas, seeking to adapt to their visitors (Falk and Dierking, 2000). Art museums have long been studying and summarily conveying similarly overarching cultural messages to the public in very meaningful ways. The materiality of art museums, venues and objects, is not an obstacle to their mission, but rather the means they use to foster a deep cultural education in a wide conception that includes environmental aspects (Leopold, 1949). This blend between venue, materiality and culture somehow makes children and adults rarely forget a visit. Even considering that those visits took far less time than those learning attempts in the classroom that escape memory far more frequently. This capacity to remember the visits -sometimes for life- may well indicate how meaningfully, how deeply the materiality of museums can convey deep environmental messages so that they integrate into visitors' lives through a potentially lifelong personal cultural development and commitment (NRC, 2009).

The interaction of art museum education with other educational disciplines can be configured as an interesting field of study. Thus, through common, complex and synergetic action, it is possible to broaden the limits and horizons of knowledge and of the methods and forms of learning that can take place in museums. For example, Environmental Education (EE) has important messages to convey. It is a discipline that promotes with its own methods the resolution of environmental problems and the restoration of an adequate human-nature link (Novo, 2003). They do not solely address emotions or partial areas of knowledge. They aim at changing behaviours in the real world on issues of material, personal and cultural consequence for individuals and society. Education has to fight a narrow understanding of what 'scientific' or 'environmental' means, and convey it as it is: a profound aspect of society and culture, linked to the whole of our being, and not just a partial, experimental or material issue. Education has to reach a core of human and cultural transcendence.

Art museums share with the environment their material side (given by objects and venues), which is transcended by the culture that objects, and the particular atmosphere of museums, embody and convey to the visitors. Together with learner motives and backgrounds and associated learning expectations, we have to count on 'the cognitive, social, and cultural learning processes and outcomes that are shaped by distinctive features of particular settings (NRC, 2009)'. The representation of reality through artworks can be a complementary way of helping to understand the reality that surrounds us. Art is not something to dismiss in the human world: this is an important thought for environmental educators. We all love to see and experience some way or another those valuable things we have to learn. And we end up loving more those environmental and cultural values we may see and feel. Art materiality is powerful in involving emotions in meaningful learning. The importance of art in the human and cultural world is one of the reasons why environmental education should be taught not as a separate discipline, but rather as a discipline common to all careers and walks of life. Our art is necessary to understand the human being properly, from whatever area of cultural expertise we address it. Art can connect us ultimately with 
the ecological environment that surrounds us and makes our existence possible. Unfortunately, specialization in career training may result in insufficient attention to the synergic action that art and environment can contain. Art museums are open to as wide a spectrum of visitors as possible. And they can assume the role to teach us the depth of our materiality to allow us to also understand the roots of ecological and environmental problems, and make amends for this unfortunate shortage in environmental education.

People matter. Art museums have evolved towards becoming enticing and meaningful to increasing numbers of people. Education has to adapt itself to the circumstances of those it addresses. The theory of significant learning formulated by Ausubel (1968), the basis of the theory of Education (Novak, 1977), provides a conceptual framework that can guide the educational actions that take place in the Art museums and that can include the objectives, contents and methods proposed by EE (Novak, 1980). To be meaningful, it has to pay attention to their previously acquired knowledge, attitudes and skills. Not only concepts count, but behaviour, in order to make living and personally and collectively building a more human life and world possible. If anything, education is about people. Not about facts. People are also at the core of environmental concerns and education, which are material, but not only. They are of personal importance (Scheuering, 2004).

Environmental education is about caring for people and their environment, inseparably. Not just one should prevail: both have to, or neither will eventually, as they are both called to life and to live. The natural world has to be more and more recognized as of human concern. Culture has to admit that the rules of nature should be considered always in terms of personal, human consequence. And we should understand ourselves more and more as people who belong to the community of land (Leopold, 1966).

The aim of this research is twofold. First, it ultimately seeks to educate on environmental related issues by bringing together some of the expertise behind the meaningful learning theory, environmental education, and museology. This aspect of the research attempts to unite these fields of expertise into a synthetic understanding in search of their joint potential to support the design of strategies for museum-based meaningful learning interventions. Second, the research seeks to show that this synthetic understanding can effectively provide a sound base to design specific environmental educational programs in art museums. This assesses the application of the potential scope of the combination of environmental education, meaningful learning and art museum experience.

\section{Methodology}

The methodology used has been a bibliographic search of the conceptual frameworks of environmental education, museum education and the theory of meaningful learning that underpins both disciplines. From the bibliographic search, a synthetic research work has been carried out, looking for common points between both disciplines in a way that is aligned with the characteristics of the theory of meaningful learning. This synthetic work includes synergetic and complementary possibilities. The main result of the study is shown below in the form of a summary table. 


\section{The complementarity and synergistic action between Environmental Education, Museology and Meaningful Learning}

\section{Environmental Education}

Environmental Education (EE) is conceived as a discipline that tries to give an educational response to the environmental crisis (Palmer and Neil, 1994). The recommendations already applied in the so-called Tbilisi Conference (Unesco, 1978) include aspects such as "making individuals and communities understand the complex nature of the natural and the built environments resulting from the interaction of their biological, physical, social, economic and cultural aspects" or "acquire the knowledge, values, attitudes, and practical skills to participate in a responsible and effective way in anticipating and solving environmental problems", including "aesthetic values". This discipline has developed since its inception in the so-called Stockholm Conference in 1972 (United Nations, 1973). In its more than forty years of existence, numerous plans, strategies and programs have carried out various actions aimed to restore an adequate person-nature relationship (Palmer, 1998). This allows an ability to overcome this environmental crisis, addressing the main environmental problems that threaten the planetary ecosystem equilibrium, in local and global levels. During these years, it has sought to achieve the intentions for which it was born (United Nations, 1973). But in reality, perhaps because it constitutes a dynamic and immensely complex field of study and interpretation (Palmer, 1998), the difficulty of fulfilling its objectives is clear, as revealed by Gigliotti (1990).

Environmental problems do not decline, but progress (Howell and Allens, 2016). The current pressing dimension of the old and the emergence of new environmental problems, such as global warming, place us in a still worrisome scenario that generates a perception of immobility or even regression in the achievement of the objectives intended by EE. This is why there is a permanent need to propose and test fresh educational initiatives that may help in improving our environmental behaviour, not only in schools, and not only outdoors but indoors. There is a need to give a boost to EE, even to look for alternative EE (Tsevreni, 2011; Schlottmann, 2012; Uzun and Keles, 2012) like the one that can be promoted in museums. John Dewey's writings (Dennis and Knapp, 1997), and Aldo Leopold's classic 'A Sand County Almanac' (Leopold, 1949) show that the sense of community, our belonging to the land, is of paramount importance for EE (Goralnik and Nelson, 2011). Museums can contribute immensely to fostering this sense and help advance the goals of EE.

\section{Museology}

Museums may be excellent environments for learning (Hein, 1998, 2000, 2012; Hooper-Greenhill, 2005, 2006, 2007; Falk, 1992, 2000, 2009; Burnham and Kai-Kee, 2011). Their role in society keeps growing in the eyes of society, and is permanently under discussion. From a cultural perspective, they are deemed instrumental in attaining higher levels of democratisation (O'Neill, 2008). Museums capture and convey cultural values, and yet they may become a mere tool in the hands of government policy (Holden, 2004). They may also be seen as 'institutions charged with both developing and embodying civic virtue and identity' (Castaneda, 2009). The social and educational roles assigned to museums evolve with society and education trends and in accordance with their own cultural field of interest (Moreno, 2004). 
Historical studies on museums (e.g. Genoways and Andrei, 2008; 0’Neill, 2008) may be of interest to 'any field that claims the public sphere as either its principle object of study or primary realm of scholarly practice' (Castaneda, 2009). The interest of an evolutionary and historical approach applies also to other museum-related learning venues, such as education libraries (Attebury and Kroth, 2012). Museums' evolution can be seen in the context of educational trends and schools of thought (Delors, 1996). But they are also influenced by many factors (NRC, 2009). It has been suggested for example that economic and professional pressures were the driving forces behind the transformation of community museums, which emerged during the late 1960s and early 1970s and transformed the traditional conception of an art museum (Moreno, 2004).

Museums act as mediators in learning. They offer unique opportunities to teach in an informal environment (NRC, 2009). They play their educational role in connection to other museum activities that should not be dismissed (Mayer et al. 2013). The importance of their educative purpose, the public they address, and their role as mediators has evolved over time (Zana, 2005). They open to a widening spectrum of people, and offer an excellent opportunity to convey education (Gómez, Balsari, Nusbaum, Heerboth and Lemery, 2013). The educative potential of museums may reach far, and combine very well with the task of teachers at schools (Kisiel, 2012).

Apart from non-educative factors, present-day education in museums shares in their historical educative background and experience, and it helps in order to understand the roots, the present and the possible future educational roles of museums. In any case, a historical approach to them conveys useful lessons to understand what has changed and what remains in present-day educative proposals in museums, and why. And to figure out what can be done in each venue and time, with its opportunities and constraints. For example, EE can find in this possibility of museum education a platform to achieve its objectives.

\section{Meaningful learning}

Novak's theory of education $(1977,1998)$ has played an influential role in EE and museum education advancement. His education theory proposes teaching techniques that build on the meaningful learning theory (Ausubel, 1968). This theory provides a theoretical framework that has proven effective in improving learning processes (Mayer, 2004). Meaningful learning is defined as 'the formation of viable relationships among ideas, concepts, and information' (Williams and Cavallo, 1995). Both authors (Ausubel and Novak) propose educational approaches that have been applied frequently in EE and Museum Education to foster knowledge about what the reality is, and improvements in behaviour, attitudes and values.

Ausubel's and Novak's contributions to meaningful learning theory may have its shortcomings and face misinterpretations. They have been challenged, of course. Meaningful learning has sometimes been seen as opposed to rote memorization. But it is unlikely, however, that such discrete categories of learning exist. Rote and meaningful learning, rather, are endpoints along a continuum of learning (Grove and Lowery Bretz, 2012). In any case, meaningful learning and the constructivist approach keep providing fresh effective guidance in teaching (Brandriet, Ward and Bretz, 2013; Garbett, 2011; Hartle et al., 2012) and inspiring environmental education initiatives (Novak, 1980; Guruceaga, 2001). 
Apart from concept building, the role of emotions has been also analysed in the meaningful learning context (Reis and Roth 2009; Boekaerts, 1988). This would encourage an educational process properly integrating 'thought, feeling and action' (Gowin, 1981, p. 11), as art museums can also enable the education of emotional intelligence (Goleman, 1996).

\section{Complementarity and synergistic action}

While developing the research in the three fields of expertise separately (i. e. museology, environmental education and meaningful learning) it became increasingly clear that their respective fields blend very well with each other in order to inspire and justify a sound educative proposal. For example, to begin with, one soon finds a common initial through the 'slow look' promoted by museums and the need to live more slowly that promotes environmental education (Novo, 2010). Museums can help in this task. Table 1 summarizes some of the concepts characteristics and proposals found during the research that exemplify this mutual complementarity and possibility of synergy. The issues of cultural depth, materiality, and the importance of the public in education. Following these chosen topics of focus, a suggestion of how the three fields of expertise connect and support each other to inspire and find a possible educational proposal can be set forth. The application of these three theoretical frameworks in art museums fits in with the proposals of Delors (1996) on the four pillars that support education for the XXI century: learning to know; learning to create, learning to live together and learning to be. The development of these skills involves education in multiple intelligences (Gardner, 2010), including intrapersonal and interpersonal ones and the intelligence to handle emotions (Goleman, 1996). This conceptual basis allows us to explore the potential of art museums to work on environmental education in a different and enabling way, open to a complex and changing world.

Table 1. Points held in common by the theoretical frameworks of Museology, Environmental Education and Meaningful Learning.

\begin{tabular}{|c|c|c|}
\hline Museology & Environmental Education & Meaningful Learning \\
\hline $\begin{array}{l}\text { Promote interactivity, hands-on } \\
\text { contact with museum objects, } \\
\text { experiential and affective } \\
\text { education. (Hooper-Grennhill, } \\
\text { 2005, p. 106), (Hooper- } \\
\text { Greenhill, 2006, pp. 238-245) }\end{array}$ & $\begin{array}{l}\text { Promote learner's active } \\
\text { involvement in learning } \\
\text { process, and experiential } \\
\text { education. (Tbilisi Conference, } \\
\text { Unesco, 1977) }\end{array}$ & $\begin{array}{l}\text { Promote active and experiential } \\
\text { learning methodologies. Use of } \\
\text { affectivity to boost meaningful } \\
\text { learning. (Gowin, 1981, p. 11; } \\
\text { Moreira, 2006) }\end{array}$ \\
\hline $\begin{array}{l}\text { Intend to familiarise society } \\
\text { with the contents and concepts } \\
\text { of objetcs and exhibitions. } \\
\text { (Zubiaur, 2004, p. 61) }\end{array}$ & $\begin{array}{l}\text { Use environmental sciences } \\
\text { contents to reach a better } \\
\text { knowledge of the environment. } \\
\text { (Unesco-PNUMA, 1994, p. } 121 \text { ) }\end{array}$ & $\begin{array}{l}\text { Curriculum planning, and learning, } \\
\text { must be based on the most } \\
\text { meaningful concepts (Zabala, 1997, } \\
\text { p. 58). }\end{array}$ \\
\hline $\begin{array}{l}\text { Adapt the museum } \\
\text { programmes to the target age } \\
\text { bracket of the public.( Hooper- } \\
\text { Greenhill, 2005, p. 114-118) }\end{array}$ & $\begin{array}{l}\text { Adapt the environmental } \\
\text { education syllabi to the age } \\
\text { bracket of students. (Unesco- } \\
\text { PNUMA, 1994, p. } 21-23 \text { ) }\end{array}$ & $\begin{array}{l}\text { Adapt the education syllabi to the } \\
\text { age bracket and psychological } \\
\text { development of students. (Piaget } \\
\text { and Inhelder, 1980) }\end{array}$ \\
\hline $\begin{array}{l}\text { Adapt the museum activities to } \\
\text { the visiting public's knowledge. } \\
\text { (Hooper-Greenhill, 2005, p. } \\
\text { 138-140) }\end{array}$ & $\begin{array}{l}\text { Adapt activities and contents to } \\
\text { the population's socio-cultural } \\
\text { context. (Unesco-PNUMA, 1994, } \\
\text { p. 39) }\end{array}$ & $\begin{array}{l}\text { Base learning activities on the } \\
\text { learners' previous stock of } \\
\text { knowledge. (Ausubel, 1976, p. 56) }\end{array}$ \\
\hline
\end{tabular}


Table 1. Continuation

\begin{tabular}{|c|c|c|}
\hline Museology & Environmental Education & Meaningful Learning \\
\hline $\begin{array}{l}\text { Pay attention to the intangible } \\
\text { heritage, which includes values. } \\
\text { (Lee, 2004; Pastor, 2004, p. 44) }\end{array}$ & $\begin{array}{l}\text { Promote education in } \\
\text { environmental values. (Unesco- } \\
\text { PNUMA, 1994, pp. 30-31) }\end{array}$ & $\begin{array}{l}\text { Promote education in values, } \\
\text { sometimes through the hidden } \\
\text { curriculum. (Mayer, 1998) }\end{array}$ \\
\hline $\begin{array}{l}\text { Encourage active information } \\
\text { searches on the museum } \\
\text { objects by visitors. (Beyer, } \\
2004 \text { ) }\end{array}$ & $\begin{array}{l}\text { Promote information search } \\
\text { and critical discrimination. } \\
\text { (Unesco-PNUMA, 1987, p. 25) }\end{array}$ & $\begin{array}{l}\text { Learners must build up their } \\
\text { knowledge by selecting the } \\
\text { information meaningful to them. } \\
\text { (Novak, 1998, p. 21; Ausubel, } \\
1976, \text { p. } 450 \text { ) }\end{array}$ \\
\hline $\begin{array}{l}\text { The museum should act as a } \\
\text { learning facilitator, furnishing } \\
\text { users with information. } \\
\text { (Hooper-Greenhill, 2005, pp. } \\
\text { 114-118) }\end{array}$ & $\begin{array}{l}\text { Educators should act as } \\
\text { facilitators and promoters of } \\
\text { environmental knowledge. } \\
\text { (Unesco-PNUMA, 1994, p. 27) }\end{array}$ & $\begin{array}{l}\text { Teachers should act as learning } \\
\text { facilitators. (Ausubel, 1976, p. } \\
514 \text { ) }\end{array}$ \\
\hline $\begin{array}{l}\text { Intend seductive, thrilling } \\
\text { learning processes. } \\
\text { (Hooper-Greenhill, 2007, pp. } \\
\text { 170-187) }\end{array}$ & $\begin{array}{l}\text { Education must be favoured by } \\
\text { motivation. (Quetel and } \\
\text { Souchon, 1985: 11; Caduto } \\
\text { 1992, p. 9) }\end{array}$ & $\begin{array}{l}\text { Meaningful learning is favoured by } \\
\text { motivation. (Mayer, 2004) }\end{array}$ \\
\hline $\begin{array}{l}\text { Interdisciplinar. Seek to } \\
\text { integrate scientific knowledge } \\
\text { within popular culture. } \\
\text { (Asensio, 1987) }\end{array}$ & $\begin{array}{l}\text { Promote the integrated } \\
\text { understanding of } \\
\text { environmental and socio- } \\
\text { economic issues. } \\
\text { (Unesco-PNUMA 1994, p. 23) }\end{array}$ & $\begin{array}{l}\text { Integrated contents favour } \\
\text { understanding and the detection of } \\
\text { conceptual errors. (Mayer 2004, p. } \\
\text { 152) }\end{array}$ \\
\hline $\begin{array}{l}\text { Promote a context of fun-based } \\
\text { learning, inspiration, and } \\
\text { creativity. (Beyer 2004; Valdés } \\
1999, \text { p. 138) }\end{array}$ & $\begin{array}{l}\text { Occasional use of simulation } \\
\text { games as educative } \\
\text { methodology. (Taylor, 1993). }\end{array}$ & $\begin{array}{l}\text { Occasional use of play as an } \\
\text { educative methodology. (Ballester, } \\
\text { 2002) }\end{array}$ \\
\hline $\begin{array}{l}\text { Learning processes must be } \\
\text { programmed to reach out any } \\
\text { age bracket. (Valdés, 1999, p. } \\
\text { 138) }\end{array}$ & $\begin{array}{l}\text { Seek a lifelong durable, } \\
\text { forward-looking education. } \\
\text { (Unesco-PNUMA, 1994, p. 64) }\end{array}$ & $\begin{array}{l}\text { Understand learning as a lifelong } \\
\text { process (Novak, p. 1998). }\end{array}$ \\
\hline $\begin{array}{l}\text { Pay attention to relations } \\
\text { between concepts, and promote } \\
\text { complex thinking. (Screven, } \\
\text { 1993; Beyer, 2004) }\end{array}$ & $\begin{array}{l}\text { The environment is a complex } \\
\text { reality, and must be approached } \\
\text { in an integrated way. (Unesco- } \\
\text { PNUMA, 1994, p. 21) }\end{array}$ & $\begin{array}{l}\text { Use concept maps to foster the } \\
\text { understanding of relations among } \\
\text { concepts (Novak, 1998, p. 21) }\end{array}$ \\
\hline $\begin{array}{l}\text { Promote local-based and } \\
\text { universal learning. (Valdés, } \\
1999, \text { p. 138) }\end{array}$ & $\begin{array}{l}\text { Promote the attitude: 'Think } \\
\text { globally, act locally'. (Unesco- } \\
\text { PNUMA, 1994, pp. 87-94) }\end{array}$ & $\begin{array}{l}\text { Intend to reach general knowledge } \\
\text { from the learners' immediate } \\
\text { particular setting. (Mayer, 2004) }\end{array}$ \\
\hline $\begin{array}{l}\text { Adapt to each personal } \\
\text { experience and cognitive } \\
\text { structure, and promote critical } \\
\text { thinking. (Moreno, 2002, p. } \\
\text { 181) }\end{array}$ & $\begin{array}{l}\text { Promote personal critical } \\
\text { thinking, e. g. in decision-taking } \\
\text { procedures. (Unesco-PNUMA, } \\
1994, \text { p. 30) }\end{array}$ & $\begin{array}{l}\text { Learning process should be } \\
\text { adapted to each personal } \\
\text { experience and cognitive structure. } \\
\text { (Novak, 1998) }\end{array}$ \\
\hline $\begin{array}{l}\text { Allow freedom of movement } \\
\text { (itineraries) to visitors, and the } \\
\text { selection of alternative points } \\
\text { of interest. (Lapaire, 1983, p. } \\
\text { 76; Cameron, 1971) }\end{array}$ & $\begin{array}{l}\text { Promote freedom in decision- } \\
\text { taking and problem solving. } \\
\text { (Unesco-PNUMA, 1994, p. 31) }\end{array}$ & $\begin{array}{l}\text { Promote a personalisation of the } \\
\text { learning, and divergence of } \\
\text { contents among divergent people. } \\
\text { (Ballester, 2002) }\end{array}$ \\
\hline $\begin{array}{l}\text { Conduct research on museology } \\
\text { (Hooper-Greenhill, 1998, p. 9) }\end{array}$ & $\begin{array}{l}\text { Conduct research in } \\
\text { environmental education. } \\
\text { (Unesco-PNUMA, 1994, p. 29) }\end{array}$ & $\begin{array}{l}\text { Conduct research on learning } \\
\text { processes (Zabala, 1997) }\end{array}$ \\
\hline $\begin{array}{l}\text { Pay attention to communication } \\
\text { processes. (Hernández, 1998) }\end{array}$ & $\begin{array}{l}\text { Consider the environmental } \\
\text { educator as a communicator. } \\
\text { (Unesco-PNUMA, 1994, pp. 29- } \\
\text { 35; Quetel, and Souchon, 1985, } \\
\text { p. 11) }\end{array}$ & $\begin{array}{l}\text { Tap into the learners' centres of } \\
\text { interest, to reach a better } \\
\text { communication. (Ausubel, 1976, p. } \\
\text { 450; Mayer, 2004, p. 251) }\end{array}$ \\
\hline
\end{tabular}


Table 1. Continuation

\begin{tabular}{|c|c|c|}
\hline Museology & Environmental Education & Meaningful Learning \\
\hline $\begin{array}{l}\text { The public must be studied, } \\
\text { well-known. (Hooper-Greenhill, } \\
\text { 1998, p. 9) }\end{array}$ & $\begin{array}{l}\text { Conduct studies of behaviour, } \\
\text { and on how the environment is } \\
\text { perceived. (Benayas, 1992) }\end{array}$ & $\begin{array}{l}\text { Conduct studies of constructivist } \\
\text { applications. Knowledge of } \\
\text { previous ideas. (Ballester, 2002) }\end{array}$ \\
\hline $\begin{array}{l}\text { Adapt to the diversity of the } \\
\text { public. (Pastor, 2004, p. 55) }\end{array}$ & $\begin{array}{l}\text { Adapt to the diversity of the } \\
\text { public. (Unesco-PNUMA, 1994, } \\
\text { p. 37) }\end{array}$ & $\begin{array}{l}\text { Personalisation of the learning. } \\
\text { Provide divergence of contents for } \\
\text { divergent students. (Ballester, } \\
\text { 2002) }\end{array}$ \\
\hline $\begin{array}{l}\text { Do not forget the importance of } \\
\text { the presence of and contact } \\
\text { with real objects. (Hooper- } \\
\text { Grennhill, 2005: 106; Rivière, } \\
\text { 1989, p. 280) }\end{array}$ & $\begin{array}{l}\text { Real experiences can boost a } \\
\text { favourable attitude towards the } \\
\text { environment. (Giordan, 1993, p. } \\
\text { 37) }\end{array}$ & $\begin{array}{l}\text { Real experiences can boost } \\
\text { motivation, emotion and } \\
\text { meaningful learning. (Ausubel, } \\
\text { 1976, p. 450) }\end{array}$ \\
\hline $\begin{array}{l}\text { Learning the competencies for } \\
\text { XXI centuty (Delors, 1996) }\end{array}$ & $\begin{array}{l}\text { Learning the competencies for } \\
\text { XXI centuty (Delors, 1996) }\end{array}$ & $\begin{array}{l}\text { Learning the competencies for XXI } \\
\text { centuty (Delors, 1996) }\end{array}$ \\
\hline $\begin{array}{l}\text { Development of Multiple } \\
\text { Intelligences (Gardner, 2010) }\end{array}$ & $\begin{array}{l}\text { Development of Multiple } \\
\text { Intelligences (Gardner, 2010) }\end{array}$ & $\begin{array}{l}\text { Development of Multiple } \\
\text { Intelligences (Gardner, 2010) }\end{array}$ \\
\hline $\begin{array}{l}\text { Development of emotional } \\
\text { intelligence (Goleman, 1996) }\end{array}$ & $\begin{array}{l}\text { Development of emotional } \\
\text { intelligence (Goleman, 1996) }\end{array}$ & $\begin{array}{l}\text { Development of emotional } \\
\text { intelligence (Goleman, 1996) }\end{array}$ \\
\hline
\end{tabular}

\section{Application of the table: a practical example}

Table 1 allows to extend some of the powers that present the disciplines exposed separately. The museum artistic context allows working on environmental education from a different perspective. As an example of the educational possibilities offered by the combination of these disciplines, the case of their application to students at university level is shown. Specifically, an educational instruction called "Landscape Workshop" was designed for the subject "Society and Environment" belonging to the Environmental Sciences degree of the Science Faculty of the University of Navarra. This environmental education workshop took place at the University of Navarra Museum. Through abstract art, from the work "Más allá de la ceniza" (1977) by the artist and beauty ecologist César Manrique (Echarri and Echarri, 2018), various notions of landscape were worked on. First of all, in the exhibition rooms, work was done on the education of the gaze and the interpretation of what is looked at, through the "visual thinking" methodology (Yenawine, 2013) which promotes perception, the feeling towards what is looked at and the routine of thought "I see, I think, I wonder". In addition, the workshop included the compilation of a landscape "footprint" that the students had to intervene in an artistic way. Finally the instruction ended with an explanation and sharing of the works made by the students.

In this way, key principles of EA are worked on, such as the interdisciplinary nature and complexity of the environment, the holistic perspective, which are reflected in the concept of landscape, understood in an integral way, including its aesthetics. The use of artworks for the teaching of environmental content was highly valued by the students.

The instruction applied educational criteria suggested by the theory of meaningful learning, such as starting from previous knowledge and the singularities and centers of interest of the students, and sought experiential education and the integration of the emotional component in the teaching at the Art Museum. 


\section{Conclusions}

This research work has been conceived to unify the most representative educational aspects of several disciplines, and tools, in a productive way. The synthesis carried out has found common criteria contents and possibilities involving museology, environmental education and meaningful learning. All these fields have an educational potential. Their joint consideration in an art museum adds up to more than the sum of their separate possibilities. Their integration may inspire specific educational programmes, which keep coherence with the criteria of each field separately. In sum, this article has involved research that has brought together different fields of theoretical, practical and conceptual knowledge seeking for synergy, and producing educational proposals.

The activities programmed in the "Landscape Workshop", as an example of the joint application of the theoretical frameworks on display, are based on the motivating capacity of the Museum's objects to promote understanding of the major environmental challenges, and the personal discovery of the role that behaviour itself can play in these challenges. They also seek to be playful, participatory and collaborative, all to facilitate the emotional involvement of the learner, and meaningful learning.

The social environment is changing and any educational syllabus has to innovate constantly to keep pace with these changes. At the same time, to bring to date or design new syllabi a sufficiently tested basis that may underpin new educative ideas is needed. The theoretical and practical synthesis of the disciplines carried out provides a new and coherent base for designing alternative educational syllabi in art museums that can work environmental education from a complex perspective, taking advantage of the benefits that museology can bring to the significance of learning in education for the twenty-first century, like the exposed "Landscape workshop".

\section{References}

Asensio, M. (1987). Adolescencia y aprendizaje. Enfoque interdisciplinar en el diseño curricular. Cuadernos de pedagogía, 149, 81-85.

Attebury, R., y Kroth, M. (2012). From Pedagogical Museum to Instructional Material Center: Education Libraries at Teacher Training Institutions, 1890s to 1970s. Libraries, Education, 35(1-2), 48-58.

Ausubel, D. (1968). Educational Psychology: A cognitive view. New York: Holt, Rinechart and Winston. [Translated to Spanish in 1976. Trillas, México].

Ballester, A. (2002). El aprendizaje significativo en la práctica. Cómo hacer el aprendizaje significativo en el aula. http://eduteka.icesi.edu.co/pdfdir/ElAprendizajeSignificativoEnLaPractica.pdf.

Benayas, J. (1992). Paisaje y educación ambiental, evaluación de cambios de actitudes hacia el entorno. Madrid: MOPT, Centro de Publicaciones.

Beyer, M. (2004). Ciencia y cultura: paradojas de un objeto al interior de un museo de ciencias. https://ilamdocs.org/documento/2933/ 
Boekaerts, M. (1988). Motivated learning: bias in appraisals. International Journal of Educational Research 12(3), 267-280. https://doi.org/10.1016/08830355(88)90005-5.

Brandriet, A., Ward R., y Bretz, S. (2013). Modeling meaningful learning in chemistry using structural equation modeling. Chemistry Education Research and Practice, 14(4), 421-430. DOI:10.1039/C3RP00043E.

Burnham, R., y Kai-Kee, E. (2011). Teaching in the Art Museum: Interpretation as Experience. Los Angeles, CA.: Getty Publications.

Caduto, M. (1992). A Guide on Environmental Values Education. (Environmental Education Series No. 13 of the Unesco-Unep). Madrid: Libros de la Catarata.

Cameron, D. (1992). Problèmes de langage en interprétation muséale. In M. O. De Barry, and F. Wassermans (Eds.), Vagues. Une anthologie de la nouvelle museology. Vol. 1, (pp. 271-276). Savigny-le-Temple: Éd. W. Mâcon and MNES.

Castaneda, T. (2009). Museum Origins: Readings in Early Museum History and Philosophy. (Book review). Public Historian, 31(1), 139-141.

Delors, J. (1996). Los cuatro pilares de la educación. In La educación encierra un tesoro. Informe a la UNESCO de la Comisión internacional sobre la educación para el siglo XXI. $\quad$ Madrid:

Santillana/UNESCO. http://uom.uib.cat/digitalAssets/221/221918_9.pdf.

Echarri, F., y Echarri, V. (2018). Significant life experiences and their relationship with the education of the scrutinizing gaze in the beauty ecologist César Manrique. The Journal of Environmental Education, 49, 411-428.

Dennis, L. y Knapp, D. (1997). John Dewey as Environmental Educator. The Journal of Environmental Education 28(2), 5-9. https://doi.org/10.1080/00958964.1997.9942817.

Falk, J (2009). Identity and the Museum Visitor Experience. Walnut Creek, CA: Left Coast Press.

Falk, J. Y Dierking, L. (1992). The Museum Experience. Washington, DC: Whalesback book.

Falk, J. H., y Dierking, L. D. (2000). Learning from museums: visitor experiences and the making of Meaning. Walnut creek, Ca.: Altamira press.

Garbett, D. (2011). Constructivism Deconstructed in Science. Teacher Education 36(6), 36-49. doi:10.14221/ajte.2011v36n6.5.

Gardner, H. (2010). La inteligencia reformulada. Las inteligencias múltiples en el siglo XXI. Madrid: Paidós. (1 ${ }^{a}$ ed. 2001).

Genoways, H., y Andrei, M. (2008). Museum Origins: Readings in Early Museum History and Philosophy. Walnut Creek, CA: Left Coast Press.

Gigliotti, L. (1990). Environmental Education: What Went Wrong? What can be Done? The Journal of Environmental Education, 22(1), 9-12. 
Giordan, A. (coord.). (1993). Educación ambiental: principios de enseñanza y aprendizaje. (Environmental Education Series No. 20 of the Unesco-Unep). Bilbao: Libros de la Catarata.

Goleman, D. (1996). Inteligencia emocional. Barcelona: Editorial Kairós.

Gómez, A., Balsari, S., Nusbaum, J., Heerboth, A., y Lemery, J. (2013). Perspective: Environment, biodiversity, and the education of the physician of the future. Academic medicine : journal of the Association of American Medical Colleges 88(2), 168-72. DOI: 10.1097/ACM.0b013e31827bfbeb.

Goralnik, L., y Nelson, M. (2011). Framing a Philosophy of Environmental Action: Aldo Leopold, John Muir, and the Importance of Community. The Journal of Environmental Education 42(3), https://doi.org/10.1080/00958964.2010.526152.

Gowin, D. (1981). Educating. New York: Ithaca. Cornell University Press.

Grove, N., y Lowery Bretz, S. (2012). A continuum of learning: from rote memorization to meaningful learning in organic chemistry. Chemistry Education Research and Practice 13 (3), 201. https://doi.org/10.1039/C1RP90069B.

Guruceaga, A. (2001). Aprendizaje significativo y educación ambiental. Tesis doctoral (Resumen en castellano). Universidad Pública de Navarra, Pamplona.

Hartle, R., Baviskar, S., Smith, R., Consulting, S., Sciences, B., Smith, A. Y Smith, F. (2012). A Field Guide to Constructivism in the College Science Classroom : Four Essential Criteria and a Guide to their Usage. Bioscene: Journal of College Biology Teaching 38(2), 31-35.

Hein, G. (1998). Learning in the Museum. New York: Routledge.

Hein, H. (2000). The Museum in Transition. A Philosophical Perspective. Washington, DC: Smithsonian Books.

Hein, G. (2012). Progressive Museum Practice: John Dewey and Democracy. Walnut Creek, CA: Left Coast Press.

Hernández, F. (1998). El museo como espacio de comunicación. Gijón: TREA.

Holden, J. (2004). Capturing Cultural Value. How culture has become a tool of government policy. London: Demos.

Hooper-Greenhill, E. (1998). Los museos y sus visitantes. Gijón: TREA.

Hooper-Greenhill, E. (2005). Museums and the interpretation of visual culture. Nueva York: Routledge.

Hooper-Greenhill, E. (2006). The power of museum pedagogy. In Genoways, H. Museum philosophy for the twenty-first century. Oxford: Altamira Press.

Hooper-Greenhill, E. (2007). Museums and education: purpose, pedagogy, performance. New York: Routledge.

Howell, R. A., y Allen, S. (2016). Significant life experiences, motivations and values of climate change educators. Enrironmental Education Research, 25(6), 813-831. 
Kisiel, J. (2012). Introducing Future Teachers to Science Beyond the Classroom. Journal of Science Teacher Education 24(1), 67-91. https://doi.org/10.1007/s10972-012-9288-x.

Lapaire, C. (1983). Petit manuel de muséologie. Suiza: Paul Haupt Berne et Sttutgart.

Lee, Y. (2004). Una urna para preservar la vida: salvaguardia y legado del patrimonio cultural inmaterial. Noticias del ICOM, 57(4), 5-7.

Leopold, A. (1966). A Sand County Almanac. Reprint, New York: Oxford Univ. Press.

Mayer M. (1998). Educación ambiental: de la acción a la investigación. Enseñanza de las Ciencias 16(2), 217-231. http://www.raco.cat/index.php/Ensenanza/article/viewFile/21530/21364.

Mayer, R. E. (2004). Psicología de la educación. Enseñar para un aprendizaje significativo. Madrid: Pearson Educación.

Mayer, G., Coyne, J., Losos, J., Foufopoulos, J., Shubin, N., Futuyma, D., Campbell, B. and Edwards, S. V. (2013). Museums' Role: Increasing Knowledge. Science 339, 11481149. https://doi.org/10.1126/science.339.6124.1148-b.

Moreira, M. (2006). Aprendizaje significativo: de la visión clásica a la visión crítica. Conferencia de cierre del $V$ Encontro Internacional sobre Aprendizaje Significativo, Madrid, España, Setiembre de 2006 http://www.if.ufrgs.br/ moreira/visionclassicavisioncritica.pdf.

Moreno, M. (2004). Art museums and socioeconomic forces: the case of a community museum. Review of radical political economics, 36(4), 506-527. https://doi.org/10.1177/0486613404269781.

National Research Council. (2009). Learning science in informal environments. People, places, and pursuits. National Research Council Commitee on Learning Science in Informal Environments. P. Bell, B. Lewenstein, A. W. Shouse, y M. A. Feder (Eds.) Washington, D. C.: The national academies press. https://www.nap.edu/catalog/12190/learning-science-in-informalenvironments-people-places-and-pursuits

Novak, J. (1977). A Theory of education. Ithaca: Cornell University Press.

Novak, J. (1980). A theory of education as a basis for environmental education. Environmental science research 18, 129-138. https://doi.org/10.1007/978-14684-3713-3_12.

Novak, J. (1998). Learning, creating, and using knowledge: concept maps as facilitative tools in schools and corporations. New York: Lawrence Erlbaum Associates, Inc.

Novo, M. (2003). La educación ambiental. Bases éticas, conceptuales y metodológicas. Madrid: UNESCO/ Universitas.

Novo, M. (2010). Despacio, despacio. 20 razones para ir más lento. Madrid: Ediciones Obelisco.

O’Neill, M. (2008). Museums, professionalism and democracy. Cultural Trends 17(4), 289-307. 
Palmer, J. (1998). Environmental education in the 21st century: Theory, practice, progress and promise. London, England: Routledge.

Palmer, J., y Neal, P. (1994). The handbook of environmental education. London and New York: Routledge.

Pastor, M. (2004). Pedagogía museística. Nuevas perspectivas y tendencias actuales. Barcelona: Ariel Patrimonio.

Piaget, J., y Inhelder, B. (1980). La psychologie de l'enfant. Translated by Morata. Madrid: Morata.

Quetel, R., y C. Souchon. (1985). Educación ambiental: hacia una pedagogía basada en la resolución de problemas. (Programa Internacional de educación ambiental. Unesco-PNUMA. № 15). Bilbao: Los libros de la Catarata.

Reis, G., y Roth. W. (2009). A Feeling for the Environment: Emotion Talk in/for the Pedagogy of Public Environmental Education. The Journal of Environmental Education 41(2), 71-87. doi:10.1080/00958960903295217.

Rivière, G. (1989). La muséologie. Cours de Muséologie / textes et témoignages. Tours: Dunod.

Schlottmann, C. (2012). Conceptual Challenges for Environmental Education: Advocacy, Autonomy, Implicit Education and Values. New York: Peter Lang New York.

Screven, C. (1993). Estudios sobre visitantes. Museum Internacional XLV(2), 4-5. http://unesdoc.unesco.org/images/0009/000951/095158so.pdf.

Taylor, J. (1993). Guía de simulación y de juegos para la educación ambiental. (Environmental Education Series No. 13 of the Unesco-Unep). Bilbao: Libros de la Catarata.

Tsevreni, I. (2011). Towards an environmental education without scientific knowledge: an attempt to create an action model based on children's experiences, emotions and perceptions about their environment. Environmental $\begin{array}{llll}\text { Education } & \text { Research } & 17 & \text { 53-67. }\end{array}$ https://doi.org/10.1080/13504621003637029.

UNESCO (1978). Interngovernmental Conference of Environmental Education, Tbilisi, URSS,1977. Final report. Paris: UNESCO. httsps://www.gdrc.org/uem/ee/EETbilisi_1977.pdf.

UNESCO. (1994). Estrategias para la formación del profesorado en educación ambiental. (Environmental Education Series No. 25 of the Unesco-Unep, 1987). Bilbao: Libros de la Catarata.

UNESCO. (1996). Tendencias de la educación ambiental a partir de la conferencia de Tbilisi. (Environmental Education Series No. 13 of the Unesco-Unep, 1994). Bilbao: Libros de la Catarata.

United Nations (1973). Declaration of the United Nations Conference on the Human Environment. New York: United Nations Publication. https://digitallibrary.un.org/record/523249?ln=es 
Uzun, F. Keles, O. (2012). The Effects of Nature Education Project on the Environmental Awareness and Behavior. Procedia - Social and Behavioral Sciences 46: 2912-2916. https://doi.org/10.1016/j.sbspro.2012.05.588.

Valdés, M. C. (1999). La difusión cultural en el museo: servicios destinados al gran público. Gijón: TREA.

Williams, K., y Cavallo. A. (1995). Relationships between reasoning ability, meaningful learning and students' understanding of physics concepts. Journal of College Science Teaching 24(5), 311-314.

Yenawine, P. (2013). Visual thinking strategies. Using art to deepen learning across school disciplines. Cambridge: Harvard education press.

Zabala, A. (1997). La práctica educativa. Cómo enseñar. Graó, Barcelona.

Zana, B. (2005). History of the museums, the mediators and scientific education. Journal of Science Communication 4(4), 1-6.

Zubiaur, F. J. (2004). Curso de museología. Gijón: TREA. 